\title{
What influences European private forest owners' affinity for subsidies?
}

\begin{abstract}
This study analyses the linkages between private forest owners' perceptions of forest management, and their affinity for subsidies, in a range of European countries. Society increasingly requires the provision of ecosystem services from forests, but the willingness of forest owners to redirect management goals from wood production to the provision of public goods is crucial for sustaining ecosystem services. EU incentives in the forestry sector are still mainly oriented towards an anthropocentric vision of forest management. Forest owners and managers are diverse, and although many efforts have been made to understand the role of forest subsidies in private forest management, it is still necessary to analyse the different perspectives on forest subsidies with a regional comparative approach. This paper explores European private forest owners' affinity for subsidies - through survey data at European leveland estimates an ordered probit model to (i) analyse how private forest owners in Europe respond to subsidies in forestry, including regional differences in terms of affinity for subsidies, (ii) characterise the factors that influence these responses and (iii) discuss lessons learned related to forest owners' attitudes on subsidies and the implications for introducing similar kind of incentives such as payments for ecosystem services. Simulations were conducted to examine the potential effects of changes in property fragmentation or the time allotted to forest activities. Forest owners with an utilitarian view of forest management, bigger forest holdings, full or part-time farmers and forest owners from East Europe are most in favour of forest subsidies. Property fragmentation and absenteeism decreases affinity for subsidies.
\end{abstract}

Keywords: Subsidies, European conservation policy, forest management, conceptualisation, private forest owners, social-ecological restoration

\section{Introduction}

The EU has established many mechanisms for protecting ecosystems, greening the EU economy, and safeguarding people's health and quality of life. Income support and the market measures in the Common Agricultural Policy (CAP) help meet the EU's strategic goals on environmental protection and rural development. The CAP was initially conceived as a vehicle for motivating agricultural production and promoting self-sufficiency through direct subsidy payments, and the CAP has gradually evolved into a complex multifunctional policy instrument to achieve a range of objectives (e.g., rural development, ecosystem conservation, resource efficiency, and more balanced income distribution) (EC, 2012). In addition to supporting the agricultural sector through the European Agricultural Guarantee Fund (EAGF), the CAP is operationalised by the European Agricultural Fund for Rural Development (EAFRD), which complements the system of direct payments to farmers with other measures that help achieve the targets set in the EU's rural development policy.

One of the priority areas in the EU's rural development policy is forestry. Sustainable forest management is central to several national and regional rural development programmes (e.g., the Portuguese Rural Development Programme, 2014-2020; Austrian 2014-2020 Programme for the Development of Rural Areas that funds the implementation of forest-related measures for private forests). Co-financing of forestry measures under the Rural Development Regulation represents the main means of EU-level funding for sustainable forest management, forest protection and delivery of ecosystem services. Rural development programmes provide subsidies for many 
activities which contribute to sustainable forest management such as forest tending or the implementation of certification schemes (e.g., eucalyptus in Galicia, cork in Catalonia).

However, within rural development programmes (that facilitate the flow of money from the EAFRD), substantially less money has been allocated to the forestry sector than to the agricultural sector. One could speculate that since private forest owners are not the primary audience of these programmes and the money available to them is rather small, they are not interested in performing the subsidized activities. Forest affinity for forest subsidies has been explored before in many contexts such as cost-sharing programmes (Song et al., 2014; Sun et al., 2009; Sun, 2007) and particularly in relation to wood mobilisation, where owners' attitudes to incentives and advise have been widely explored (Lawrence, 2018). Numerous studies have shown that private forest owners in Europe are mostly multi-objective owners, recreationists, indifferent owners or conservationists and not-for-profit managers (see Ficko et al., 2017 for a review). A rapid assessment of 42 studies on UK forest owner attitudes and decisions undertaken by Lawrence and Dandy (2014) suggests that landowners are not primarily motivated by making money from woodlands and that many woodland owners in the UK perceive non-intervention as a positive management option. A review of interventions to increase wood mobilisation found that, of hundreds of studies, only a few examine the factors affecting adoption of measures such as subsidies; and they find a wide range of factors, varying in a non-consistent way (Lawrence, 2018). For example, older forest owners are more likely than younger owners to harvest in most regions, but the reverse is found in some regions. This paper explores the regional differences in Europe in order to analyse the forest owner interest in forest subsidies and the socio-ecological factors driving their interest. Understanding the views of forest owners about accepting financial incentives in forestry may shed light on the functioning of forest subsidies as a mechanism supporting sustainable forest management and rural development.

In theory, subsidies can influence production and management through four mechanisms: (i) by changing the relative price of factors and products; (ii) by directly affecting revenues that impact investment and labour decisions; (iii) by changing risk perceptions because of the subsidies insurance effect, and (iv) by fostering farm growth or exiting the industry (Kumbhakar and Lien, 2010; Zhu and Oude-Lansink, 2010).

The influence of agricultural subsidies on farm performance in practice has been widely analysed, mainly in terms of crop production (Quiroga et al., 2017; Kumbhakar and Lien, 2010). However, there is little research on the efficiency of the complex support from the rural development programmes to forestry (e.g., Jarský et al., 2014, Uthes et al., 2017). Some others have focused on specific programmes related to agroforestry (Brescancin et al., 2017, Desjeux et al., 2014, Sarvašová et al. 2017) or to specific measures that address agriculture and forestry jointly (Caruso et al., 2015, Sin and Nowak, 2014). The economic advantages of subsidies from the rural development programmes for afforestation of agricultural lands for forest owners and farmers have been emphasized by Jarský and Pulkrab (2013) in Czech Republic; Lawrence and Dandy (2014) in UK; Moons and Rousseau (2007) and Van Gossum et al. (2007) in Belgium; Tassone et al. (2004) in Italy; Karali et al. (2014) in Switzerland; Larsen et al. (2013) in Denmark, among others.

Empirical studies on subsidized forest management have often come to contrasting conclusions. Some authors have found that governmental subsidies had an adverse effect on economic performance of the forestry sector (Aoyagi and Managi, 2004), while others found that subsidies had a positive influence on the technical efficiency of forest products (Aclkgoz and Mack, 2012). These contrasting results may be due to the lack of empirical studies about the latent drivers of natural resource management: the biocentric versus the anthropocentric perception of forest management. Sociological and socio-psychological studies have shown that a substantial amount of the variability in the concern for forests can be explained by human values and general attitudes about the environment. Studies on environmental worldviews show that proenvironmental orientation is a strong predictor of conservation support (e.g., Kaltenborn and Bjerke, 2002; Van Riper and Kyle, 2014; Rhead et al., 2015). In contrast, an anthropocentric view of the relationship between humans and nature that emphasizes the material or physical benefits nature can provide may positively influence private forest owner affinity for subsidies. 
There are also economic factors which influence forest management. Economic development has been shown to be a strong determinant of environmental concern in post-industrial countries (e.g., Franzen and Vogl, 2013). Therefore, one could expect that forest owners from more developed countries are less interested in receiving money for managing their forests than their counterparts from less developed countries because of their stronger sense of environmentalism, but this may depend on whether the subsidy money for forest management addresses nature values of the forest or profitability of timber production. Feliciano et al. (2017), for instance, showed that small-scale forest owners from Western Europe considered ecosystem centred management more important, while owners from Eastern Europe considered economic aspects and forest maintenance more important. Pursuing income through forest management may also be linked to the size of forest holdings and the socio-demographic profile of a forest owner. While large-scale private forest owners and large-scale, full-time owners consider income a top priority (e.g., Stanislovaitis et al., 2015), most of the small-scale forest owners in Europe do not have the same priorities (Ficko et al., 2017) or at least do not consider forest management "a good business opportunity" or "an opportunity to earn additional money" (Feliciano et al., 2017). An attitude towards forest management as an economic activity may be further characterised by forest property attributes such as the number of fragmented and scattered forest parcels, openness of forests and the distance from an owner's residence to the forest parcels. The resulting effect of these factors may not entirely be a consequence of the economies of scale but also relate to the level of place attachment. Place-attachment studies have identified a positive correlation between management orientation and the level of emotional or social attachment to the landscape (e.g., Lokocz et al., 2011). It is reasonable to assume that forest owners living far from forests have weaker emotional bonds to their properties and would be less interested in subsidies in comparison to forest owners living near their properties. This might be affected by other emotional ties, such as, depending on whether the property is inherited or purchased from the market.

Interest in forest subsidies may also be affected by the payment mechanisms and the origin of the money. Support for forestry within Rural Development Programmes can be divided into two parts - project-oriented support and flat rate support (i.e., payments per hectare). In certain countries, in addition to the support from the EU funds, there is also support from the national/regional sources. For example, in the Czech Republic, support from national sources is focused on regular forest management, while the Rural Development Programme support focuses on the larger and more expensive projects that are supported by flat rates. Jarský (2017), among other authors, showed that there is substantial interest in changing this fragmented system among the public that is involved in forestry. Forestry professionals and academia preferred replacing the current subsidies system with payments for ecosystem services and the flat rate system. The interviewed forest owners strongly preferred the universal flat rate payments that would be similar to direct payments to owners. It can be assumed that had such a system of flat rate payments been implemented interest in subsidized forest measures would increase significantly.

Farmer decisions differ between different farmer types, and according to their characteristics and attitudes and land use change trajectories have been related to socio-demographic factors such as globalization of agricultural markets, the transition from a rural to an urban society, and the shift to post-socialism in central and eastern Europe (Feliciano et al., 2017; van Vliet et al., 2015; Præstholm et al, 2006). However, little attention has been placed on the regional comparison when analysing the response to concrete incentives such as subsidies. Here we aim to address this gap, exploring regional differences on the factors that influence European private forest owner attitudes to forest subsidies.

This paper is structured as follows: First, we surveyed private forest owners in six European countries about their affinity for forest subsidies. Second, we used an ordered probit model to estimate the probability of forest owner to be interested in forest subsidies. Third, we calculated the marginal effects of forest owner socio-demographic profiles on their interest in forest subsidies. Finally, a simulation of potential structural change in forest owner socio-demographic profiles was performed to analyse how changes in socio-demographic profiles and forest holding properties may increase or decrease interest in forest subsidies. 


\section{Methods}

\subsection{Conceptual and methodological framework}

Figure 1 shows a framework for the analysis in this paper. The aim of our analysis is to characterise forest owner affinity for subsidies in response to different influencing factors, such as management concept, size, and dedication, and to explain potential behavioural changes in response to changes in forest owner types. The red numbers in Figure 1 show the steps in the analysis: we [1] estimate the probability of forest owner affinity for subsidies in terms of management goals, demographic drivers and forest land characteristics, then [2] calculate the predicted response to the determinants of these perceptions, and finally [3] simulate potential behavioural changes as a response to changes in forest owner typologies related to influential factors, such as fragmentation, forest properties and dedication to forestry. We use the estimated models to simulate the cumulative probability of the forest owners' responses in terms of the proposed changes.

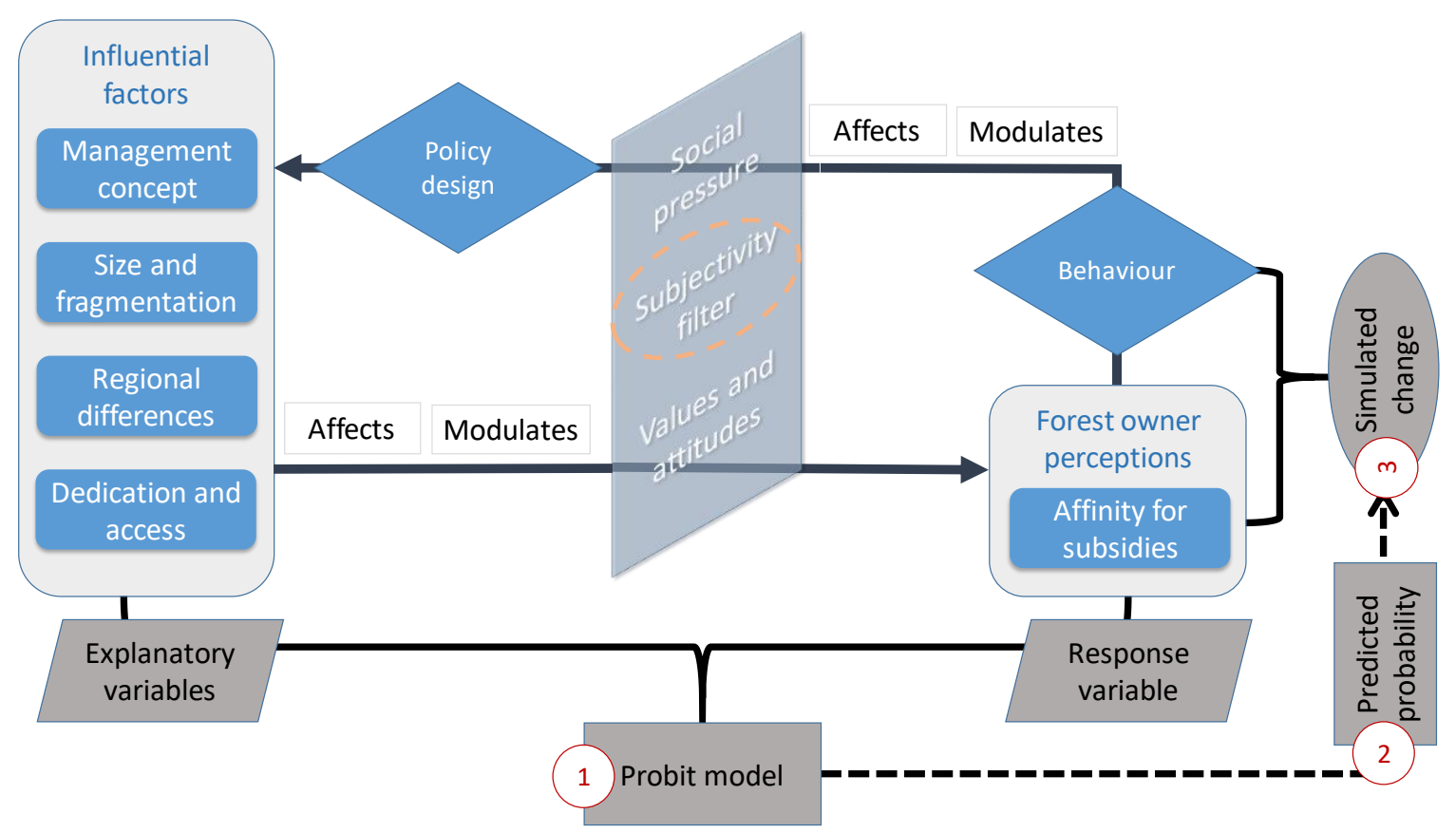

Figure 1: Overall approach and methodology

Despite the high diversity of meanings associated with social representation models, such as this one, the core elements are consensual and relatively stable (Abric, 2001), and aim at studying the influence of social factors in thinking processes through the identification and characterization of relationship structures. However, this consistency and stability does not imply that social representations do not vary across the countries. The representation of a social group should be interpreted within the framework of existing knowledge structures - here the influential factors supported by previous literature - and should always consider a more holistic approach that integrates various attitudinal components —or subjectivity filters- affecting individual perceptions and behaviour (Buijs, 2009).

The selection of the candidate predictors in the model was based on:

1. the vast literature on private forest owner typologies which shows that attributes of the individuals, such as socio-demographic profiles or property attributes, characterize the differences between private forest owner types (e.g. Burton, 2004) and influence forest owner types, forest management attitudes, and behaviour (e.g. Follo et al., 2017);

2. social representations theory of Moscovici (2008). This theory assumes that the members of groups and communities share similar value systems, beliefs and opinions. It may thus 
be assumed that latent variables such as private forest owners' perceptions of forest management or worldviews play a major role in forest owners' affinity for forest subsidies. We assumed that the anthropocentric view of forest management is more likely to be associated with forest owners' affinity for forest subsidies than biocentric concepts such as conservation-oriented forest management or ecosystem-centred management. The anthropocentric view of forest management represents the utilitarian view on nature, where nature is valued because of material or physical benefits it can provide for humans.

We consider here the following influencing factors: (i) management concept, (ii) property size and fragmentation of land ownership, (iii) factors affecting regional differences and (iv) the level of job type of dedication (full-time vs part-time) and access to the forest (in terms of distance). A range of studies have found these factors to be relevant drivers of forest owner behaviour including the following.

(i) Management style: many studies suggest that landowners are not primarily motivated by earning money from woodlands (Lawrence, 2018; Stanislovaitis et al., 2015; Lawrence and Dandy, 2014). Ficko and Boncina (2013) emphasised that the economically rational behaviour of materialist forest owners is not necessarily based on a utility maximisation strategy but on historical and social backgrounds.

(ii) Size and fragmentation: the pursuit of income from forest management is strongly linked to the size of forest holdings and although still no consensus exist about that, some recent studies find that mainly larger private forest owners regard income as a top priority (Feliciano et al., 2017; Stanislovaitis et al., 2015). Fragmentation is the process of dividing large forest holdings into smaller forest holdings. This process can result from various institutional, political and sociological factors such as urbanisation, property restitution, transaction costs in land markets or by the death of the forest owners and the subsequent distribution of the land for inheritance purposes (Jongman, 2002; Schmithüsen and Hirsch, 2010)

(iii) Regional differences: Bouriaud et al. (2013) found that in Eastern European countries, forest owner perceptions of management differ from those in Western European countries, owing to differences in political systems and the consequences of post-socialist forest privatisation processes. Feliciano et al. (2017), for instance, showed that small-scale forest owners from Western Europe considered ecosystem issues centred management more important, while owners from Eastern Europe considered economic aspects and forest maintenance more important.

(iv) Dedication and access. How far forest owners live, and how much time they spend working there, can affect their relationship with the ecosystem and the emotional bond they develop with it. Blombäck et al. (2012) provided evidence that type of employment (i.e. full time versus part time) is a determinant factor for sustainable development of forests and other natural resources. Individual values and perceptions are affected and modulated by influencing factors, resulting in individual perceptions for each forest owner. This process needs to be understood to determine forest owner behaviours and the impacts on society, as policy design can be modified based on social values and pressures.

\subsection{Data}

The empirical data were collected in a survey conducted in six countries in Europe: Portugal, France, Slovenia, the Czech Republic, Slovakia and Romania. The data were collected in 20142015 as part of the COST Action FP1201 Forest Land Ownership Changes in Europe: Significance for Management and Policy (FACESMAP), except for the Slovenian data which was collected in 2013, before the Action. The data were collected via online surveys (France), written questionnaires (Slovakia and Romania), face-to-face surveys (Czech Republic) and telephone surveys. In Portugal, the data were collected through a combination of mailed, telephone, and online surveys. The number of respondents was 732, with 82 from Slovakia, 75 from Czech Republic, 42 from Romania, 200 from Slovenia, 133 from Portugal and 200 from France (Feliciano et al. 2017). 
Different sampling methods were used in the different countries. In Slovenia, random sampling was used, and snowball sampling was used in Slovakia, the Czech Republic, and Romania. Furthermore, members of forest owner associations in North and Central Portugal were sampled. A non-response bias test was conducted on the Slovenian data, and no bias was found (Ficko and Boncina, 2015). Despite different sampling methods and the fact that we did not have a full list of forest owners for each country, there is no reasonable assumption that the samples are biased, while conversely there is no proof of complete representativeness.

Respondents were asked to indicate their level of agreement with a range of statements defining forest management on a standard five-point Likert scale $(1=$ strongly disagree to $5=$ strongly agree). The statements were taken from the questionnaire used in the national study by Ficko and Boncina (2015) and the international survey by Feliciano et al. (2017), and included perceptions on forest management, ranging from biocentric approaches (hereainafter nonutilitarian), valuing nature for its own sake, to anthropocentric approaches (hereinafter utilitarian), where nature is valued because of the material or physical benefits it can provide for humans (Gagnon and Barton, 1994).

Figure 2 shows the histograms for the affinity for subsidies (dependent variable), from strongly disagree (1) to strongly agree (5). A vertical line represents the mean value for each country. It can be observed that, in general, few forest owners strongly agreed with the statement that forest management is a source of subsidies in these countries ${ }^{1}$.
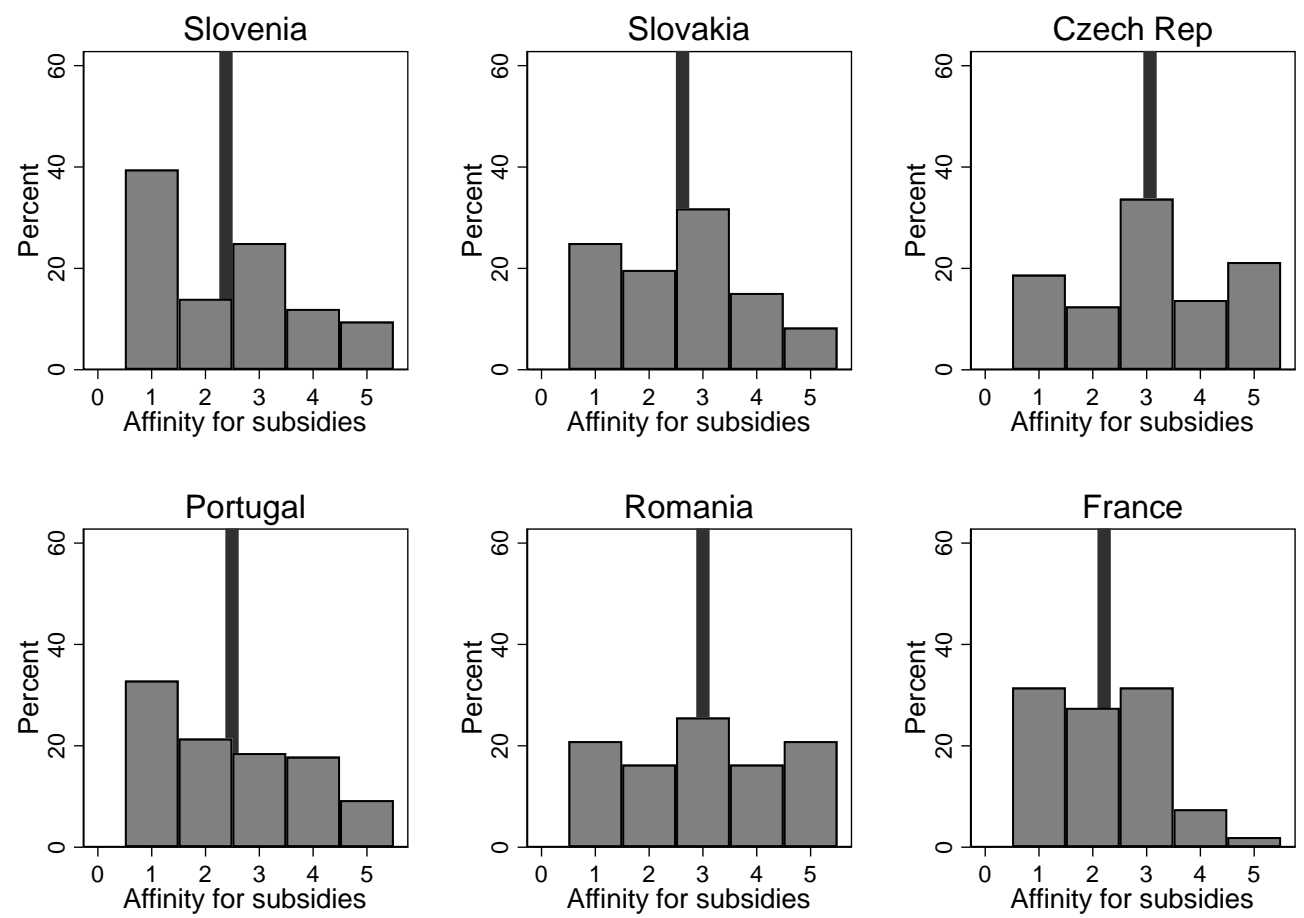

Figure 2: Survey data on affinity for subsidies in different countries surveyed

Based on the influential factors identified in the conceptual and methodological framework, Table 1 shows detailed information about the explanatory variables used and the units and main descriptive statistics. Pearson correlations among the explanatory variables were calculated and

\footnotetext{
${ }^{1}$ Analyses of the data were performed using version 15 of the STATA software.
} 
they did not show any absolute value over 0.3 and the average VIF factor was 1.09 and so does not show any collinearity problem².

Table 1: Explanatory variables of forest owner affinity for subsidies

\begin{tabular}{|c|c|c|c|c|c|}
\hline $\begin{array}{l}\text { Influential } \\
\text { factors }\end{array}$ & $\begin{array}{l}\text { Explanatory } \\
\text { variables }\end{array}$ & Definition & Units & Mean $^{*}$ & Std. Dev. \\
\hline \multirow{2}{*}{$\begin{array}{l}\text { Management } \\
\text { style }\end{array}$} & \multirow[t]{2}{*}{ Business-oriented } & \multirow{2}{*}{$\begin{array}{l}\text { Dummy variable for a self- } \\
\text { reported business-oriented view } \\
\text { of forest land (Q2 in Appendix } \\
\text { A) }\end{array}$} & $1=$ Yes & 0.1459 & $(0.353)$ \\
\hline & & & $0=\mathrm{No}$ & & \\
\hline \multirow{2}{*}{$\begin{array}{l}\text { Regional } \\
\text { differences }\end{array}$} & \multirow[t]{2}{*}{ Western Europe } & \multirow{2}{*}{$\begin{array}{l}\text { Dummy variable for region (Q3 } \\
\text { in Appendix A) }\end{array}$} & $1=$ West & 0.4536 & $(0.498)$ \\
\hline & & & $0=$ East & & \\
\hline \multirow{2}{*}{$\begin{array}{l}\text { Size and } \\
\text { fragmentation }\end{array}$} & Forest area & Property size & $\mathrm{Ha}$ & 33.2282 & $(179.355)$ \\
\hline & Plots & $\begin{array}{l}\text { Amount of forest plots (Q5 in } \\
\text { Appendix A) }\end{array}$ & Number & 10.744 & $(23.433)$ \\
\hline \multirow{8}{*}{$\begin{array}{l}\text { Access and } \\
\text { dedication }\end{array}$} & \multirow[t]{2}{*}{ Far from forest } & \multirow{2}{*}{$\begin{array}{l}\text { Dummy variable for distance } \\
\text { between the forest property and } \\
\text { living area (Q6 in Appendix A) }\end{array}$} & $1=>20 \mathrm{~km}$ & 0.2493 & $(0.433)$ \\
\hline & & & $0=<=20 \mathrm{~km}$ & & \\
\hline & \multirow[t]{2}{*}{ Full-time } & \multirow{2}{*}{$\begin{array}{l}\text { Dummy variable for full time } \\
\text { dedication to forest activities } \\
\text { (Q7 in Appendix A) }\end{array}$} & $1=$ Yes & 0.1281 & $(0.334)$ \\
\hline & & & $0=\mathrm{No}$ & & \\
\hline & \multirow[t]{2}{*}{ Part-time } & \multirow{2}{*}{$\begin{array}{l}\text { Dummy variable for part time } \\
\text { dedication to forest activities } \\
\text { (Q8 in Appendix A) }\end{array}$} & $1=$ Yes & 0.3161 & $(0.465)$ \\
\hline & & & $0=\mathrm{No}$ & & \\
\hline & \multirow{2}{*}{$\begin{array}{l}\text { No direct } \\
\text { management }\end{array}$} & \multirow{2}{*}{$\begin{array}{l}\text { Dummy variable for no time } \\
\text { dedicated to forest activities } \\
\text { (Q9 in Appendix A) }\end{array}$} & $1=$ Yes & 0.5546 & $(0.497)$ \\
\hline & & & $0=\mathrm{No}$ & & \\
\hline
\end{tabular}

\subsection{Estimating perceptions through an ordered probit model}

Ordered response models have proven a useful tool to evaluate the effects of socio-economic characteristics on stakeholder attitudes, measured on an ordinal scale (Greene and Hensher, 2010). This topic has been the subject of an increasing amount of empirical literature, particularly to understand individual perceptions about environmental issues and climate change concerns (Quiroga et al., 2015; Drake et al., 2013; García de Jalón et al., 2013; Bosselmann, 2012; Maddison, 2007; Layton and Brown, 2000). For our empirical analysis, we estimated an ordered probit model based on owner perceptions in six European countries to characterise how the probability of strongly agree $(j=5)$ to strongly disagree $(j=1)$ with a subsidized forest policy responds to owner typologies, as shown in equation [1]:

$$
Y_{i}^{*}=\beta X_{i}+\varepsilon_{i}
$$

where $Y_{i}^{*}$ is a latent measure of characterisation of subsidized forest policy perceptions; $X_{i}$ is a vector of factors that influence the owners' perceptions; $\beta$ is a vector of parameters to be estimated; and $\varepsilon_{i}$ is the error term and is assumed to have a standard normal distribution. Since we cannot observe $Y_{i}^{*}$, we can only observe the categories of responses as follows:

$$
\operatorname{Prob}\left(Y_{i}=j\right)=\operatorname{Prob}\left(\mu_{j-1}<\beta^{\prime} X_{i}+\varepsilon_{i} \leq \mu_{j}\right)
$$

\footnotetext{
2 Variance Inflation Factor (VIF) measures how much variance of an estimated regression coefficient is increased because of collinearity. If any of the VIF values exceeds 5 or 10, it implies that the associated regression coefficients are poorly estimated because of collinearity (Montgomery, 2001).
} 
The maximum likelihood technique that provides consistent and asymptotic estimators can be used to jointly estimate the vector of parameter $\beta$ and thresholds of $\mu$. The thresholds of $\mu$ indicate an array of normal distributions related to the definite values of the explanatory variables. Parameter $\beta$ denotes the influence of variation in response variables on the principal scale. According to Greene (2012), the positive sign of parameter $\beta$ implies a greater adaptive capacity as the value of related variables increase. To complete the process of variable selection, we tested for collinearity problems.

\subsection{Marginal effects and simulated probabilities}

The probability in the ordered probit model can be estimated as follows:

$$
\operatorname{Pr}\left(Y_{i}=j \mid X\right)=\left[\Phi\left(\mu_{j}-\beta^{\prime} X_{i}\right)-\Phi\left(\mu_{j-1}-\beta^{\prime} X_{i}\right)\right]
$$

where $\Phi$ is the cumulative distribution function (CDF) of a standard normal random variable. The marginal effects of changes in response variables are calculated for the estimated coefficients of the ordered probit model for a quantitative variable as:

$$
\frac{\partial \operatorname{Pr}\left(Y_{i}=j \mid X\right)}{\partial X}=\left[\phi\left(\mu_{j-1}-\beta^{\prime} X_{i}\right)-\phi\left(\mu_{j}-\beta^{\prime} X_{i}\right)\right] \beta
$$

and for a discrete variable $\left(\Delta X_{m}\right)$ :

$$
\Delta \operatorname{Pr}\left(Y_{i}=j \mid X\right)=\operatorname{Pr}\left(Y_{i}=j \mid X+\Delta X_{m}\right)-\operatorname{Pr}\left(Y_{i}=j \mid X\right)
$$

\section{Results and discussion}

\subsection{Estimated affinity for subsidies}

Table 2 shows the estimated model for the affinity for subsidies. The magnitude and sign of the estimated coefficients should not be interpreted as a direct impact in this probit model, but we can say that an increase in a variable with a positive coefficient increases the probability that the dependent variable will be in the highest category (strongly agree) yet decreases the probability that it will be in the lowest category (strongly disagree) (see also Quiroga et al., 2015 for the interpretation). We can observe that forest owners with business-oriented forest management style are more in favour of forest subsidies than those with a conservation or heritage objective. Forest owners from the Western European countries seems to perceive less forest management as a source of subsidies than forest owners from Eastern Europe. Bouriaud et al. (2013) also determined that in Eastern European countries forest owner perceptions of management differ from those in Western European countries due to differences in the political systems and to the consequences of the forest privatisation process in the Eastern countries. Socio-demographic characteristics such as gender and age were not significant predictors explaining the affinity for subsidies, so these factors were removed from the estimated model to gain efficiency and

\begin{tabular}{|c|c|c|c|c|}
\hline Influential factors & $\begin{array}{l}\text { Explanatory } \\
\text { variables }\end{array}$ & Coef. & Std. Error & \\
\hline Management style & Business-oriented & 0.7707 & $(0.114)$ & $* * *$ \\
\hline Regional differences & Western Europe & -0.1511 & $(0.083)$ & * \\
\hline \multirow{2}{*}{ Size and fragmentation } & Forest area & 0.0004 & $(0.000)$ & * \\
\hline & Plots & -0.0045 & $(0.002)$ & * \\
\hline \multirow{3}{*}{ Access and dedication } & Far from forest & -0.1589 & $(0.095)$ & $* * *$ \\
\hline & Full-time & 0.4190 & $(0.124)$ & $* * *$ \\
\hline & Part-time & 0.2348 & $(0.090)$ & $* * *$ \\
\hline
\end{tabular}
improve the interpretability.

Table 2: Ordered probit estimation of affinity for subsidies 


\begin{tabular}{lrr}
\hline LR chi $^{2}(7)$ & 80.20 & ${ }^{* \star \star}$ \\
Observations & 732 & \\
\hline \hline
\end{tabular}

Note: ${ }^{*} p<0.1 ;{ }^{* *} p<0.05 ;{ }^{* * *} p<0.01$.

Figure 3 shows the estimated marginal effects of the determinants of the perception of forest management as a source of subsidies. These effects tell us to how much an increase or decrease of an explanatory variable changes the probability of responding to each of the five categories the respondents could choose in the dependent variable. Figure 3 illustrates the means of the marginal effects and confidence intervals (95\%) corresponding to estimations in Table 2. By comparing variables and their marginal effects calculated from equations [4] and [5], respectively graphically (Fig. 3) we can identify qualitative and quantitative variables with greatest effects. The reference line at 0 is shown as a reference for significant coefficients (those variables that do not touch the reference line are significant determinants).
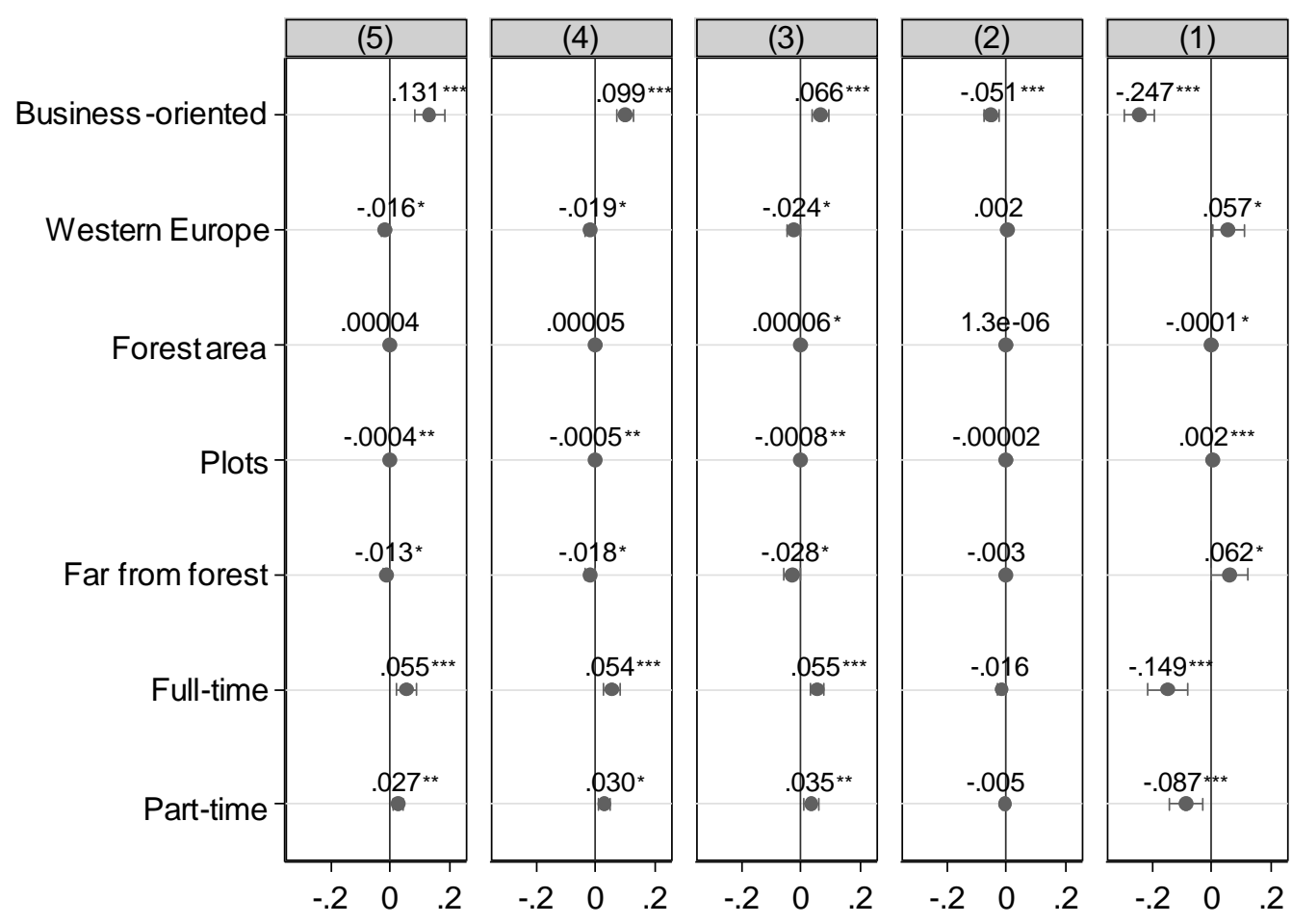

Figure 3. Marginal effects for the determinants of affinity for subsidies.

Note: (5) Strongly agree, (4) Agree, (3) Neutral, (2) Disagree, (1) Strongly disagree. ${ }^{*} p<0.1{ }^{* *} p<0.05 ;{ }^{* \star *} p<0.01$.

\subsection{A simulation of potential structural change}

Responses to potential structural changes of forest owner characteristics have been simulated to understand the effect of these changes on the perception of forest management as a source of subsidies in Europe. Simulated cumulative probabilities for forest owner affinities for subsidies are presented in Figure 4. We can observe that, in general, the forest owners with a businessoriented management style are dedicated to economic activities, have a higher probability of strongly agreeing with subsidies, independently of the level of dedication (part-time, full-time) to forest activities. Forest owners working full time on forest management agreed more probably with a subsidy policy that those working part time of forest management. Since perception of forest management as a source of subsidies vary across countries, it is necessary to recognize the diversity as an important consideration when designing the policy instruments. Therefore, subsidies oriented policies seem not to be sufficient as management incentives. Although the EU 
Forest Strategy stresses the importance of sustainable forest management, and it advises on the design and implementation of economic instruments to improve coordination and achieve forest policy goals, these are usually not adopted or poorly implemented at the national levels (Sotirov et al, 2015). In that sense, current management incentives may benefit if they were supplemented or reoriented to include incentives that motivates forest owners to manage for nonbusiness purposes.

Many studies (e.g., Stanislovaitis et al., 2015) found that pursuing income from forest management is strongly linked to the size of forest holdings and that only larger private forest owners regard income as a top priority. However, Ficko and Boncina (2013) emphasised that the economically rational behaviour of materialist forest owners is not necessarily based on utility maximisation strategy but also on the historical and social background. Matilainen and Lähdesmäki (2014) showed that timber production values might be more emphasised in countries with a high proportion of private forests and free public access to nature. However, our findings (Table 2, Figure 4), do not suggest that size of forest property have a significant impact on the affinity for subsidies.
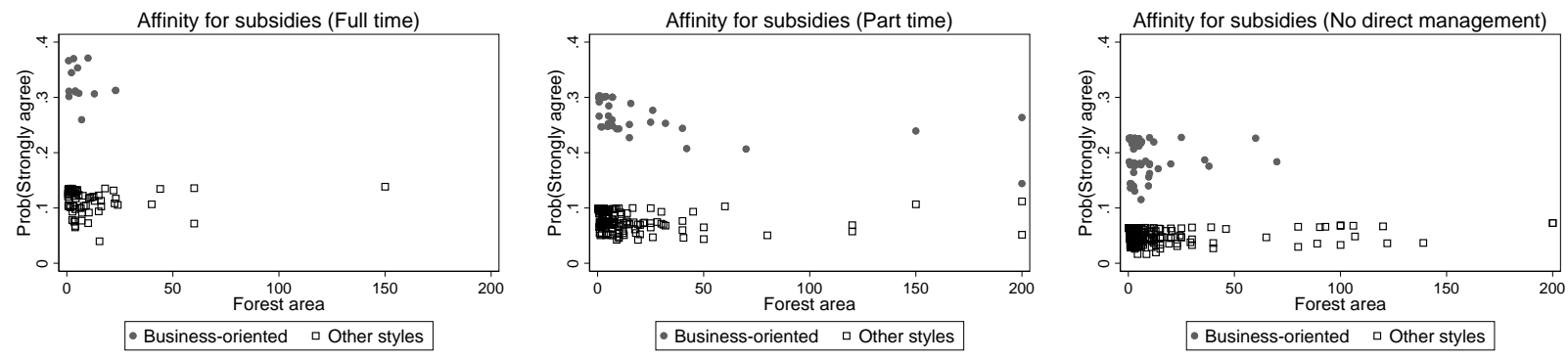

Figure 4. Simulated probability of affinity for subsidies for forest owners with business-oriented view of forest management and other styles view.

Figure 5 shows the potential response of the affinity for subsidy according to the number of plots owned by each forest owner.Figure 5 shows the simulated marginal effects - probability of change from equation [4] — for affinity for subsidies (strongly agreeing, being indifferent or strongly disagreeing) as perceived for a representative individual in the sample. A representative individual has been constructed by keeping the responses of a forest owner at their mean values for continuous variables and the median for discrete variables. Our results show a negative relationship between the number of plots owned by each forest owner and affinity to subsidies. This might be linked to fragmentation of forest properties which occurs when the area of forest is divided, or fragmented, into several smaller patches of forest ownership, habitat or management. According to Hatcher et al. (2013) fragmentation can lead to negative externalities, such as problems of economic efficiency in forest management (higher harvesting and transaction costs), disincentives for investment in forest practices, and greater management problems related to the provision of ecosystem services, including wildlife, water, recreational opportunities and soil security.: 


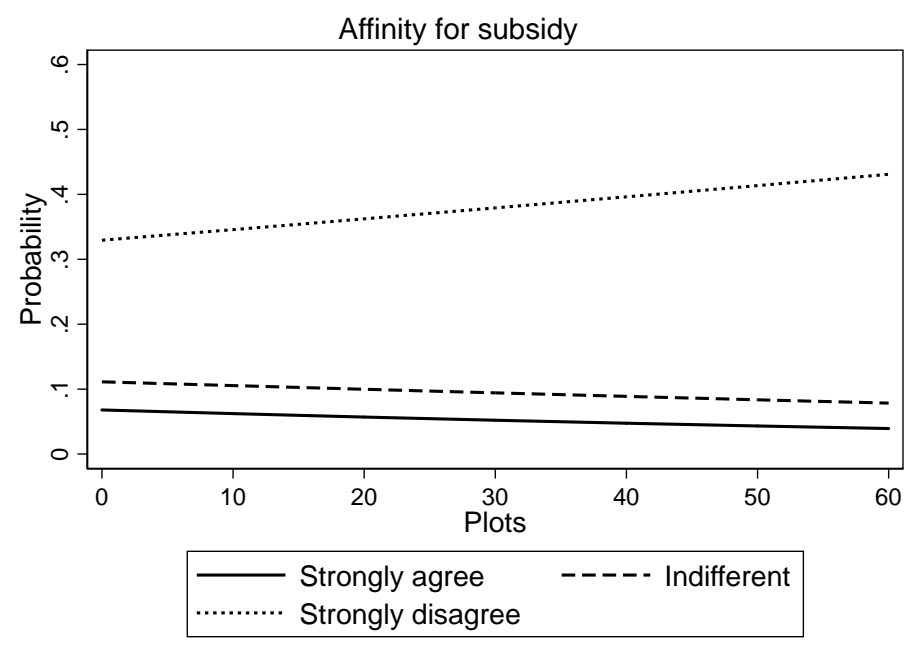

Figure 5. Simulated probability of affinity for subsidies as a response to the number of forest plots owned by each forest owner

\subsection{Some policy considerations}

Therefore, as has been previously recognized, there is an increasing diversity of private forest owners in Europe, and only a minority of studies in literature gave specific policy recommendations (Ficko et al., 2017). One of the key features of an integrated forest policy and management approach could be a process that manages conflicts related to the sustainable use and conservation of forests in a coordinated way through the application of different policy instruments (e.g. subsidies) and market incentives (Sotirov et al., 2015). However, it seems that market instruments are not capturing the main attention from forest owners when managing the forest, therefore non-market instruments are needed to achieve the EU strategy goals, as already recognized in a range of studies (Feliciano et al., 2017; Lawrence, 2018; Sotirov et al., 2015; GFC, 2013).

Recognition of ancient cultures and community conserved areas (ICCAs ${ }^{3}$ ) has proven to be highly effective in reducing forest and biodiversity loss. Socio-ecological communities not only do form an approach to forest conservation that is at least as effective as the formal establishment of protected areas, but they are far more sustainable from the social, cultural, economic, and financial points of view, protecting ancient cultures and sustainable livelihoods while not requiring a permanent external flow of funding in terms of compensation payments (GFC, 2013).

Rather, considering new approaches such as social-ecological restoration concept (FernándezMajarrés et al., 2018), identifying the level of ecosystem dependence of local people and the collective cultural value of the supporting ecosystem. Local knowledge is disappearing fast and biodiversity is not coming back without external aid, since restoration require leadership and local community commitment that is currently wanting, making the dependence on policy measures linking people with their surrounding nature, even if they include new ways of human-nature interactions (Fernández-Majarrés et al., 2018).

Some measures may include required formal legal recognition of the rights of local communities-even ancient cultures in the case of Sámi in Finland-- to their territories, land tenure systems, autonomous governance systems and bio cultural conservation approaches. In Table 3, we propose some policy actions at different levels of a social-ecological model perspective (CDC, 2014).

\footnotetext{
3 ICCAs were recognized or otherwise supported in at least eight decisions of the 11th Conference of the Parties to the CBD. See http://www.cbd.int/doc/decisions/COP-11/cop-11-dec-27-en.pdf
} 
Table 3: Policy measures proposal for different levels in a socio-ecological model perspective

\begin{tabular}{|c|c|}
\hline "Social-ecological level & Proposed measures \\
\hline Individual & $\begin{array}{l}\text { Understanding the determinants that influence behaviour change, including } \\
\text { tenure for beauty conservation, maintenance for future generations, etc. }\end{array}$ \\
\hline Interpersonal & $\begin{array}{l}\text { Promote social networks and community conserved areas (ICCAs) to recover } \\
\text { practices that can take advantage from local knowledge, including customs or } \\
\text { traditions. }\end{array}$ \\
\hline Comn & $\begin{array}{l}\text { Support to rural and urban communities, improving relationships among } \\
\text { organizations, institutions, and informational networks related to rural and } \\
\text { urban forests, including the built environment. }\end{array}$ \\
\hline Organizational & $\begin{array}{l}\text { Organizations or social institutions working together to coherently manage } \\
\text { and understand the forest. Social awareness of the importance of non-market } \\
\text { regulation forest services such as regulating water quality, biodiversity } \\
\text { protection, climate regulation, etc. }\end{array}$ \\
\hline $\begin{array}{l}\text { Policy/Enabling } \\
\text { Environment }\end{array}$ & $\begin{array}{l}\text { Formal legal recognition of the rights of local communities to their territories, } \\
\text { land tenure systems, autonomous governance systems and bio cultural } \\
\text { conservation approaches. }\end{array}$ \\
\hline
\end{tabular}

Source: Own elaboration following the CDC (2014) socio-ecological model levels.

\section{Conclusions}

European governments used a variety of financial instruments to influence forest management. The Rural Development Programmes, co-financed by the EU, were most frequently cited as the framework for support to private forest management through subsidies and incentives (FORESTEUROPE, UNECE and FAO, 2011). However, it seems that market instruments are not capturing the main attention from forest owners when managing the forest, therefore non-market instruments are needed to achieve the EU strategy goals, as already recognized in a range of studies (Lawrence, 2018; Feliciano et al., 2017; Sotirov et al., 2015; GFC, 2013).

These findings also show a low affinity for subsidies among the forest owners. . Also, Church and Ravenscroft (2008) showed that in the UK over 50\% of non-commercial owners who were not receiving management grants felt that such incentives were irrelevant and that over $30 \%$ of those receiving grants also felt they did not affect decisions. Since the main respondents of this study were small or medium scale forest owners, barriers to the uptake of forest subsidies such bureaucracy and administrative demands, uncertainty in policy and incentive schemes, loss of control over their property, and inflexible and restrictive land management regimes may not compensate for the opportunities that the subsidies might bring (Sarvašová, 2017). On the other hand, some authors (Wavehill Consulting, 2009; Ward and Manley, 2002; Betts and Ellis, 2000) suggest that forest owners might not be aware of subsidies, so they might not consider it relevant for forest management.

A range of studies have argued that an anthropocentric approach of forest management is strongly related to the size of forest holdings and therefore larger private forest owners regard income as a top priority. In our conclusion, a robust positive link exist among the businessoriented view of forest management and the affinity for subsidies. However, this connection is not associated to size of forest holdings and has more to do with the time allocated to the forest activities. Those forest owners with a higher presence in the forest activities (i.e., full time dedication) agreed more with a subsidy policy that those with less time allocated to the forest activities or those with no direct dedication to forest. Also regional factors are relevant; forest owners in West Europe show less affinity to subsidies than those in East Europe.

The increasing number of 'new' forest owners raises important questions for forest policy, especially on how policy instruments can reach these owners, via extension services for example (Hogl et al, 2005). In our findings, higher number of plots per forest owner, less time allocated to forest activities within the forest owners (moving towards partial dedication or no direct 
management of the forest properties), and other forest management styles than businessoriented view of management, the higher the probability of forest owners to be less interested by subsidies or economic incentives.

A need for new instruments that consider the diversity of forest owners and their goals is emerging as a key issue for conservation policies, understanding that sometimes forest ownership goals do not respond to economic drivers (Feliciano et al, 2017). Lessons learned about existing subsidies in the EU can be extrapolated to the introduction of new incentives based on the emergent social-ecological restoration concept (Fernández-Majarrés, 2018). Table 3 provides some examples of potential measures to be considered as part of non-market policy mechanisms.

\section{Acknowledgements}

We acknowledge the funding from the whole team from FACESMAP FPS COST Action FP1201. Also VJ was supported by the Czech National Agency for Agricultural Research (NAZV) under the contract QJ1530032.

\section{References}

Abric, J.C., 2001. L'approche structurale des représentations sociales: développements récents. Psychologie et Société, 4, 81-103.

Aclkgoz B., Mack J.A., 2012. Relation between the Efficiency of Public Forestry Firms and Subsidies: The Swiss Case. Conference Paper in International Conference on Operations Research (OR).

Aoyagi S., Managi S., 2004. The impact of subsidies on efficiency and production: Empirical test of forestry in Japan. International Journal of Agricultural Resources, Governance and Ecology, 3, 216-230.

Battese, G.E.; Broca, S.S., 1997. Functional forms of stochastic frontier production functions and models for technical inefficiency effects: A comparative study for wheat farmers in Pakistan. Journal Productivity Anaysis, 8, 395-414.

Battese, G.E.; Coelli, T.J., 1995. A model for technical inefficiency effects in stochastic frontier production function for panel data. Empirical Economics 20, 325-332.

Betts, A., Ellis, J., 2000. What Woodland Owners Want - an Attitude Survey. A Report Prepared by the Surrey Woodland Working Group.

Blombäck, P., Poschen, P., Lövgren M., 2012. Employment Trends and Prospects in the European Forest Sector. Geneva Timber and Forest Study Paper 29. United Nations, Economic Commission for Europe, Geneva, Switzerland

Bosselmann, A.S., 2012. Mediating factors of land use change among coffee farmers in a biological corridor. Ecological Economics, 80, 79-88.

Bouriaud, L., Nichiforel, L., Weiss, G., Bajraktari, A., Curovic, M., Dobrinska, Z., Glavonjic, P., Jarski, V., Sarvasova, Z., Teder, M. Zalite, Z., 2013. Governance of private forests in eastern and Central Europe: an analysis of forest harvesting and management rights. Annals of Forest Research 56, 199-215.

Buijs, A.E., 2009. Lay people's images of nature: Comprehensive frameworks of values, beliefs, and value orientation. Society and Natural Resources 22, 417-432.

Burton, M., 2004. Radical psychology networks: a review and guide. Journal of Community \& Applied Social Psychology, 14, 119-130 
Brescancin, F., Dobšinská, Z., De Meo, I., Šálka, J., Paletto, 2017. A. Analysis of stakeholders' involvement in the implementation of the Natura 2000 network in Slovakia. Forest Policy and Economics, http://dx.doi.org/10.1016/j.forpol.2017.03.013

Caruso, D., Contò, F., Skulskis, V. 2015. The implementation of measure 121 of the rural development program: Comparative analysis between Italy and Lithuania. Intellectual Economics 9: 102-107.

CDC (2014). Centers for Disease Control and Prevention (CDC), The Social Ecological Model: A Framework for Prevention, http://www.cdc.gov/violenceprevention/overview/socialecologicalmodel.html.

Church, A., Ravenscroft, N., 2008. Landowner responses to financial incentive schemes for recreational access to woodlands in south east England. Land Use Policy 25, 1-16.

Desjeux, Y., Dupraz, P., Kuhlman, T., Paracchini, M.L., Michels, R., Maigné, E., Reinhard, S. 2015. Evaluating the impact of rural development measures on nature value indicators at different spatial levels: Application to France and The Netherlands. Ecological Indicators 59: 41-61

Drake, B., Smart, J.C.R., Termansen, M., Hubacek., K., 2013. Public preferences for production of local and global ecosystem services. Reg Environ Change. 13, 649-659.

EC, European Commission, 2012. Innovating for Sustainable Growth: a bioeconomy for Europe COM (2012) Available at: http://ec.europa.eu/research/bioeconomy/pdf/official-strategy_en.pdf

Feliciano, D., Bouriaud, L., Brahic, E., Deuffic, P., Dobsinska, Z., Jarsky, V., Lawrence, A., Nybakk, E., Quiroga, S., Suarez, C., Ficko, A., 2017. Understanding private forest owners' conceptualisation of forest management: Evidence from a survey in seven European countries. Journal of Rural Studies, 54: 162-176.

Fernández-Majarrés JF, Roturier S, Bilhaut AG (2018) The emergence of the social-ecological restoration concept. Restoration Ecology, 26 (3), 404-410.

Ficko, A., Boncina, A., 2013. Probabilistic typology of management decision-making in private forest properties. Forest Policy and Economics 27, 34-43.

Ficko, A., Boncina, A., 2015. Forest owner representation of forest management and perception of resource efficiency: a structural equation modeling study. Ecology and Society 20, 36.

Ficko, A., Lidestav, G., Dhubháin, A.N., Karppinen, H., Zivojinovic, I., Westin, K., 2017. European private forest owner typologies: A review of methods and use. Forest Policy and Economics, http://dx.doi.org/10.1016/j.forpol.2017.09.010.

Follo, G., Lidestav, G., Ludvig, A., Vilkriste, L., Hujala, T., Karppinen, H., Didolot, F., Lukmine, D. 2017. Gender in European Forest Ownership and Management - Reflections on Women as "New Forest Owners". Scandinavian Journal of Forest Research, 32, 174-184.

FOREST EUROPE, UNECE, FAO, 2011. State of Europe's Forests 2011. Status and Trends in Sustainable Forest Management in Europe. Available at: http://www.unece.org/fileadmin/DAM/publications/timber/Forest_Europe_report_2011_web.pdf

Franzen, A., Vogl, D., 2013. Two decades of measuring environmental attitudes: A comparative analysis of 33 countries. Glob. Environ. Change-Human Policy Dimens. 23, 1001-1008.

Gagnon Thompson, S.C., Barton, M.A., 1994. Ecocentric and anthropocentric attitudes toward the environment. Journal of environmental psychology, 14 (2), 149-157.

García de Jalón, S., Iglesias, A., Quiroga, S., Bardají, I., 2013. Exploring public support for climate change adaptation policies in the Mediterranean region: A case study in Southern Spain. Environmental Science \& Policy, 29, 1-11

Greene, W., Hensher, D. 2010. Modeling Ordered Choices, Cambridge University Press, Cambridge.

Greene, W., 2012, Econometric Analysis, seventh ed. Pearson, USA. 
Hatcher, J., Straka, T., Greene, J. (2013). The Size of Forest Holding/Parcelization Problem in Forestry: A Literature Review Resources 2013, 2, 39-57.

Hogl K, Pregernig M, Weiß G (2005). What is new about new forest owners? A typology of private forest ownership in Austria. Small-scale Forest Economics, Management and Policy, 4 (3), 325-342.

Jarský, V., Pulkrab. K. 2013. Analysis of EU support for managed succession of agricultural land in the Czech Republic. Land Use Policy 35, 237-246.

Jarský, V., Sarvašová, Z., Dobšinská, Z., Ventrubová, K., Sarvaš, M. 2014: Public support for forestry from EU funds - Cases of Czech Republic and Slovak Republic. Journal of Forest Economics, 20, 380-395.

Jarský, V. 2017. Alternative financing options for the forestry sector - results of the analysis among academics. Reports of forestry research-Zpravy lesnickeho vyzkumu 62(2), 127-134.

Jongman, R.H.G., 2002. Homogenisation and fragmentation of the European landscape: ecological consequences and solutions. Landsc Urban Plan, 58, 211-221

Kaltenborn, B.r.P., Bjerke, T., 2002. Associations between environmental value orientations and landscape preferences. Landscape and Urban Planning 59, 1-11.

Karali, E., Brunner, B., Doherty, R., Hersperger, A., Rounsevell, M., 2014. Identifying the factors that influence farmer participation in environmental management practices in Switzerland. Human Ecology, 42,. 951-963.

Kumbhakar, S. C., Lien, G., 2010. Impact of Subsidies on Farm Productivity and Efficiency. In The Economic Impact of Public Support to Agriculture, Studies in Productivity and Efficiency, edited by Ball, V. E., R. Fanfani, and L. Gutierez, 109-124. New York, NY: Springer

Larsen, L.E., Jepsen, M.R., Frederiksen, P., 2013. Scenarios for biofuel demands, biomass production and land use-The case of Denmark. Biomass and bioenergy, 55, 27-40.

Lawrence A., Dandy N., 2014. Private landowners' approaches to planting and managing forests inthe UK: What's the evidence? Land Use Policy, 36, 351-360.

Lawrence A. (2018) Do interventions to mobilise wood lead to wood mobilisation? A critical review of the links between policy and private forest owners' behaviour. Forestry. Forthcoming.

Layton, D., Brown, G., 2000. Heterogeneous preferences regarding global climate change. Rev Econ Statistics. 82, 616-624

Lokocz, E., Ryan, R.L., Sadler, A.J., 2011. Motivations for land protection and stewardship: Exploring place attachment and rural landscape character in Massachusetts. Landscape and Urban Planning 99, 65-76.

Maddison, D., 2007. The perception of mitigation and adaptation to climate change in Africa. Policy The World Bank Development Research Group. Research Working Paper: 4308.

Matilainen, A., Lähdesmäki, M., 2014. Nature-based tourism in private forests: stakeholder management balancing the interests of entrepreneurs and forest owners? Journal of Rural Studies 35, 70-79.

Montgomery, D., 2001. Introduction to Statistical Quality Control. (4th edn) John Wiley \& Sons

Moons, E., Rousseau, S., 2007. Policy options for afforestation in Flanders. Ecological economics 64, 194-203.

Præstholm, S., Reenberg, A., Kristensen, S.P., 2006. Afforestation of European landscapes: How do different farmer types respond to EU agri-environmental schemes?. GeoJournal, 67, 71-84.

Quiroga, S., Suárez, C., Solís, J.D., 2015. Exploring coffee farmers' awareness about climate change and water needs: smallholders' perceptions of adaptive capacity. Env Sci Pol, 45, 53-66. 
Quiroga, S., Suárez, C., Fernández, Z., Philippidis, G., 2017. Levelling the playing field for European Union agriculture: Does the Common Agricultural Policy impact homogeneously on farm productivity and efficiency? Land Use Policy, 68: 179-188.

Rhead, R., Elliot, M., Upham, P., 2015. Assessing the structure of UK environmental concern and its association with pro-environmental behaviour. Journal of Environmental Psychology 43, 175183.

Sarvašová, Z., Ali, T., Đorđević, I., Lukmine, D., Quiroga, S., Suárez, C., Hrib, M., Rondeux, J., Mantzanas, K.T., Franz, K., 2017. Natura 2000 payments for private forest owners in Rural Development Programmes 2007-2013 - a comparative view. Forest Policy and Economics, http://dx.doi.org/10.1016/j.forpol.2017.08.019

Schmithüsen, F., Hirsch, F., 2010. Private Forest Ownership in Europe. Geneva Timber and Forest Study Paper 26. United Nations, Economic Commission for Europe, Geneva, Switzerland.

Sin, A., Nowak, C. 2014. Comparative Analysis of EAFRD's Measure 121 ("Modernization of agricultural holdings") Implementation in Romania and Poland. Procedia Economics and Finance 8: $678-682$.

Solís, D., Letson, D., 2013. Assessing the value of climate information and forecasts for the agricultural sector in the Southeastern United States: multi-output stochastic frontier approach. Regional Environmental Change 13, 5-14.

Song, N., Aguilar, F.X., Butler, B.J., 2014. Cost-share program participation and family forest owners' past and intended future management practices. Forest Policy and Economics, 46, 3946.

Sotirov, M., Storch, S., Aggestam, F., Giurca, A., Selter, A., Baycheva, T., Eriksson, O., Sallnäs, O., Schüll, O., Trubins, R., Borges, J., McDermott, C., Hoogstra-Klein, M., Hengeveld, G., Pettenella, D. (2015): Forest Policy Integration in Europe: Lessons Learnt, Challenges Ahead, and Strategies to Support Sustainable Forest Management and Multifunctional Forestry in the Future. INTEGRAL EU Policy Paper.

Stanislovaitis, A., Brukas, V., Kavaliauskas, M., Mozgeris, G., 2015. Forest owner is more than her goal: a qualitative typology of Lithuanian owners. Scandinavian Journal of Forest Research 30, 478-491.

Sun, X., Sun, C., Munn, I., Hussain, A., 2009. Knowledge of three regeneration programs and application behavior among Mississippi nonindustrial private forest landowners: A two-step sample selection approach. Journal of Forest Economics, 15, 187-204.

Sun, C., 2007. Variation of federal cost-share programs in the United States and the inducement effects on tree planting. Journal of Forest Economics, 12, 279-296.

Tassone, V.C., Wesseler, J., Nesci, F.S., 2004. Diverging incentives for afforestation from carbon sequestration: an economic analysis of the EU afforestation program in the south of Italy. Forest policy and economics, 6, 567-578.

Uthes, S., Li, F., Kelly, E. 2017. Does EU rural expenditure correspond to regional development needs? Land Use Policy 60: 267-280.

Van Gossum, P., Ledene, L., Arts, B., de Vreese, R., van Langenhove, G., Verheyen, K., 2009. New environmental policy instruments to realize forest expansion in Flanders (northern Belgium): A base for smart regulation?. Land Use Policy, 26, 935-946.

Van Riper, C.J., Kyle, G.T., 2014. Capturing multiple values of ecosystem services shaped by environmental worldviews: A spatial analysis. Journal of Environmental Management 145, 374384.

Van Vliet, J., de Groot, H.L.F., Rietveld, P., Verburg, P.H., 2015. Manifestations and underlying drivers of agricultural land use change in Europe. Landscape and Urban Planning, 133, 24-36.. 
Ward, J., Manley, W., 2002. New Entrants to Land Markets: Final Report. Woodland Policy Group of the GB Wildlife \& Countryside Agencies.

Wavehill Consulting, 2009. A survey of farmers with woodland on their Land. A report for the Forestry Commission Wales. Wavehill Consulting, Aberaeron, UK. Accessible at: http://www.forestry.gov.uk/newsrele.nsf/webpressreleases/84fdba74afa80d00802576dd005946d 4.

Zhu, X., Oude Lansink, A., 2010. "Impact of CAP Subsidies on Technical Efficiency of Crop Farms in Germany, the Netherlands and Sweden." Journal of Agricultural Economics 61, 545564. 


\section{Appendix A}

\begin{tabular}{ll}
\hline \hline ID & Question \\
\hline Q1 & In your view, forest management is a source of subsidies? \\
Q2 & $\begin{array}{l}\text { In your view, forest management is a good business opportunity } \\
\text { because it provides good financial revenues? }\end{array}$ \\
Q3 & $\begin{array}{l}\text { Country (West Europe if country=France, Portugal; East Europe if } \\
\text { country=Slovenia, Slovakia, Czech Republic, Romania) }\end{array}$ \\
Q4 & Total land area under your property (ha) \\
Q5 & $\begin{array}{l}\text { Number of forest plots (forest parcels) owned by the same person } \\
\text { but legally separated }\end{array}$ \\
Q6 & Average distance between home and forest holdings \\
Q7 & Forest management is a full-time job \\
Q8 & Forest management is a part-time job \\
Q9 & Forest management is not part of my job \\
\hline \hline
\end{tabular}

Note: These questions have been extracted from a wider questionnaire fully detailed in Feliciano et al. (2017).

\footnotetext{
4 This question included a Likert Scale from 0 to 5 in the survey. Here it has been transformed into a binary variable considering that those answering 4 or 5 (agree or highly agree with the statement) were considered as having a business orientation in their management (Bussiness oriented=1).
} 